\title{
Survival and growth of tree seedlings as a function of seed size in a gallery forest under restoration
}

\author{
Leonardo Gallo Macera', Silvia Rahe Pereira² and Andréa Lúcia Teixeira de Souza**
}

Received: February 24, 2017

Accepted: April 17, 2017

\begin{abstract}
Seed size is commonly related to higher rates of emergence and survival, and biomass of seedlings when introduced by direct seeding. However, few studies have evaluated whether this relationship persists when species are reintroduced as seedlings or if this effect persists after seed reserves decline. This study evaluated the effect of seed size (mass) on the probability of survival and growth of seedlings of nine native tree species introduced into a pasture area, which was originally a gallery forest in the state of São Paulo in Southeastern Brazil. The experiment occurred over the course of 24 months, in which was divided into three separate time intervals: 14 to 61 days, 61 days to 12 months, and 12 to 24 months. Seedling survival in the field was high for all three time-intervals. Seed mass positively influenced the probability of seedling survival throughout all three time-intervals after planting, but the intensity of this effect decreased with time. Species with smaller seeds exhibited higher relative growth rates (height), but only until the end of the first year. Our results suggest that seed mass is a functional trait that can predict the probability of the establishment of individual trees during forest restoration.
\end{abstract}

Keywords: functional trait, life history, nursery-raised seedling planting, pioneering species, species reintroduction

\section{Introduction}

The restoration of riparian areas and other terrestrial ecosystems is based on the reconstruction of plant communities through the reintroduction of key species (Davy 2002; Reis et al. 2003; Lamb 2005; Pilon \& Durigan 2013; Gunaratne et al. 2014), mostly through the introduction of nursery-raised seedlings (Klippel et al. 2015). The basic premise of this strategy is to decrease high mortality rates of individuals in stages of seeds and seedlings, thereby increasing the success in species establishment (Schmidt 2008; Albuquerque et al. 2010; Cole et al. 2011; Grossnickle 2012). However, studies on the probabilities of survival and growth rates of seedlings in degraded areas are still rare (Clark et al. 1999; Holl 1999; Martínez-Garza et al. 2013; Larson et al. 2015), especially in tropical forests.

Several studies showed that individuals of species with larger seeds have higher chances of surviving initial developmental stages than those with smaller seeds, mainly when growing under stressful conditions such as low light, high herbivory rates and low nutrient availability within the soil (Leishman 2001; Moles \& Westoby 2004; Baraloto et al. 2005; St-Denis et al. 2013). Further, Pereira et al. (2013), carried out an experiment including seven tree species from Brazilian Savanna which was monitored along 24 months in the field, and found that species with small seeds (smaller than $50 \mathrm{mg}$ ) were more vulnerable to competition with exotic grasses than individuals of species

\footnotetext{
${ }^{1}$ Departamento de Ciências Ambientais, Universidade Federal de São Carlos, P. O. Box. 679, 13565- 905, São Carlos, SP, Brazil

${ }^{2}$ Unidade Agrárias, Universidade Anhanguera, 79037-280, Campo Grande, MS, Brazil

* Corresponding author: altdesouza@gmail.com
} 
with larger seeds. However, most studies evaluated the relationship between seed mass and survival in direct sowing experiments (Camargo et al. 2002; Baraloto et al. 2005; Pereira et al. 2013; St-Denis et al. 2013).

Moles \& Westoby (2004) found that seed mass did not influence the probability of transition from viable seed to newly emerged seedlings of 33 species; however, this trait had a strong effect on the probability of plant survival after the first weeks of emergence. The intensity of the positive effect of seed mass on seedling survival can decline after seed reserves have exhausted (Dalling \& Hubbell 2002; Westoby et al. 2002), but seed sizes can be negatively correlated with plant relative growth rates (Cornelissen et al. 2003; Poorter \& Garnier 2007). Seed sizes are also positively related to root mass in the first developmental stages, which could be a decisive factor on the survival of young plants (Larson et al. 2015). However, it is not known whether these relationships (seed mass vs. survival and seed mass vs. growth) persist when species are reintroduced by planting nursery-raised seedlings, and if the intensity of these effects change overtime.

In this study, we evaluated the probabilities of survival and growth of nine tree species in relation to seed sizes over 24 months in a pasture area, which was originally a gallery forest. Since there is a large influence of seasonality on plant survival during the initial life stages, we evaluated three different time periods after transplanting the seedlings to the field: Time Interval I - the first two months, which are critical to plant survival; Time Interval II - the following ten months, when plants face the first unfavorable season; and Time Interval III - when mortality chances strongly decrease (Moles \& Westoby 2004). Specifically, we asked: 1) does seed size influence the probability of initial survival of seedlings (Time Interval I) in the same way that is predicted in the literature for plants introduced in seed stage? 2) does this relationship maintain over the time, in Time Interval II and Time Interval III? 3) does seed size influence the relative growth rates of the individuals over time? We expected the effect of seed size on the probability of survival to decrease over time, after the seed reserves have been exhausted.

\section{Materials and methods}

\section{Study area}

This study was carried out at Estância Dois Irmãos, located in the rural area of the São Carlos district in São Paulo State in southeastern Brazil (21 ${ }^{\circ} 54^{\prime} 43.569^{\prime \prime} S$ and

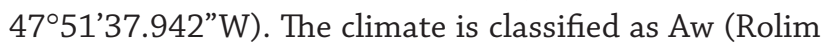
et al. 2007), subtropical with wet summer from October to March, and dry winter, between April and September. Mean annual temperatures vary between 20 and $25^{\circ} \mathrm{C}$, whereas mean annual rainfall varies between 1,138 and $1,593 \mathrm{~mm}$, averaging $1,429 \mathrm{~mm}$ (Rolim et al. 2007). The terrain is represented by Serra Geral formations, composed by volcanic rocks of basaltic flows, sandstone of the Botucatu-Pirambóia formation (Souza Junior et al. 2011). The soil of the region is composed by Red-Yellow Latosols (Rhodic Kanhapludalf), Purple Latosol, and Dark Red Latosol, with mean texture of $15-34 \%$ clay, and are considered dystrophic, presenting patches of eutrophic soils (Calderano Filho et al. 1998). The experimental area had 2,308 $\mathrm{m}^{2}$, with approximately 200 $\mathrm{m}$ in length, adjacent to a narrow gallery forest remnant, inserted in a Permanent Protection Area, with widths varying between 10 to $20 \mathrm{~m}$, next to Engenho Velho Stream. This experimental area was used as pasture, and therefore the vegetation was basically composed by exotic grasses, mainly Urochloa brizantha (A.Rich.) R.D.Webster.

\section{Experimental design}

The seedlings of the nine species used in the experiment were produced in the nursery of the Universidade Federal de São Carlos from seeds obtained regionally. The lots were examined and all seeds with any type of anomaly were discarded. Mean seed fresh mass was obtained from 200 seeds from each species from the lots used in the experiment (Tab. 1). Seed dormancy was overcome by mechanical scarification (Carvalho 2003; Salomão 2003), with the exception of Copaifera langsdorffii Desf. (Pereira et al. 2013). Seeds were disposed on Petri dishes covered with vermiculite and conditioned in a germination chamber with constant temperature $\left(28^{\circ} \mathrm{C}\right)$ and a $12 \mathrm{~h}$ photoperiod. After radicle emergence, each seed was transplanted to plastic seedling pots (volume $=290 \mathrm{~cm}^{3}$ ) containing organic substrate and coconut fiber $(20 \%)$. The plants were grown for approximately four months in the nursery, covered by $20 \%$ of shade and the seedlings were irrigated by micro-dispersion for 5 minutes, four times a day. In the last three weeks before transplanting to the field we reduced irrigation to two times a day. Field planting occurred between the 12 and 14 of February 2013. The experimental area was previously isolated from cattle and grasses were chemically removed by applying glyphosate. The whole experimental area received approximately 300 liters of solution in the concentration of $300 \mathrm{ml} / 100 \mathrm{~L}$. The first application was carried out two weeks before planting the seedlings. After planting, grasses were removed whenever their height was over $20 \mathrm{~cm}$. This procedure was conducted throughout the entire monitoring period of the experiment. After one week of herbicide application, the soil was decompressed to a depth of approximately $30 \mathrm{~cm}$. The control of leaf-cutting ants was done every two weeks during the two years of the experiment conduction. For this, visual searches of the anthills were carried out and, when necessary, we applied Fipronil insecticide.

The nursery-raised seedlings were transplanted to random plots in a grid of $2 \times 2 \mathrm{~m}$ and the disposition of species was completely randomized. We introduced 63 seedlings of Cedrela fissilis Vell., 63 of Pterogyne nitens Tul., 63 of Cariniana legalis Kuntze, 64 of Enterolobium contortisiliquum (Vell.) Morong, 61 
Table 1. Species name, species code, mean seed mass and standard deviation, wood density of the species and ecological categories used in the field experiment.

\begin{tabular}{|c|c|c|c|c|}
\hline Family / Species & Code & $\begin{array}{l}\text { Seed mass } \\
(\mathrm{mg})\end{array}$ & $\begin{array}{l}\text { Wood density } \\
\left(\mathrm{g} / \mathrm{cm}^{3}\right)\end{array}$ & Class $^{1}$ \\
\hline $\begin{array}{c}\text { Meliaceae } \\
\text { Cedrela fissilis Vell. }\end{array}$ & CEF & $41.99 \pm 7.03$ & $0.47-0.61^{*}$ & $\begin{array}{l}\text { Early secondary to } \\
\text { light-demanding climax }\end{array}$ \\
\hline $\begin{array}{l}\text { Leguminosae } \\
\text { Pterogyne nitens Tul. }\end{array}$ & PTN & $81.09 \pm 17.61$ & $0.70-0.87^{*}$ & Pioneering to late secondary \\
\hline $\begin{array}{l}\text { Lecythidaceae } \\
\text { Cariniana legalis Kuntze }\end{array}$ & CAL & $91.64 \pm 15.81$ & $0.50-0.65^{*}$ & Late secondary \\
\hline $\begin{array}{l}\text { Leguminosae } \\
\text { Enterolobium contortisiliquum (Vell.) Morong }\end{array}$ & ENC & $251.66 \pm 25.82$ & $0.37-0.60^{*}$ & Pioneering to late secondary \\
\hline $\begin{array}{l}\text { Leguminosae } \\
\text { Copaifera langsdorffii Desf. }\end{array}$ & COL & $358.45 \pm 80.31$ & $0.64-0.86^{*}$ & Late secondary to climax \\
\hline $\begin{array}{l}\text { Leguminosae } \\
\text { Enterolobium timbouva Mart. }\end{array}$ & ENT & $717.25 \pm 150.72$ & $0.37-0.60^{* *}$ & Pioneering to late secondary \\
\hline $\begin{array}{l}\text { Leguminosae } \\
\text { Platypodium elegans Vogel }\end{array}$ & PLE & $748.43 \pm 74.15$ & $0.82 * *$ & Early secondary \\
\hline $\begin{array}{c}\text { Leguminosae } \\
\text { Schizolobium parahyba (Vell.) Blake }\end{array}$ & SCP & $1808.83 \pm 259.98$ & $0.32-0.40^{*}$ & Early secondary \\
\hline $\begin{array}{l}\text { Leguminosae } \\
\text { Hymenaea courbaril L. }\end{array}$ & HYC & $5125.11 \pm 1211.70$ & $0.90-1.10^{*}$ & Late secondary to climax \\
\hline
\end{tabular}

${ }^{*}$ Carvalho (2003); ${ }^{* *}$ Lorenzi (2002). ${ }^{1}$ see review by Carvalho (2003)

of Copaifera langsdorffii, 64 of Enterolobium timbouva Mart., 61 of Platypodium elegans Vogel, 62 of Schizolobium parahyba (Vell.) Blake and 63 of Hymenaea courbaril L.. All individuals were tagged with coloured and numbered seals to enable identification of each individual.

\section{Data collection}

Fourteen days after seedling planting, we recorded survival and initial height of aboveground parts to verify if any damage caused during transportation or planting could influence the results or mortality due to changes in water availability and temperature between the nursery and the field. However, very high survival rates in this period were observed, with very low variation among species, indicating that seedling transposition had a negligible effect on plant survival: mortality rates were zero for P. nitens, $E$. contortisiliquum, E. timbouva, S. parahyba, and H. courbaril, and lower than 0.066 for the other species.

We carried out 13 observations of plant survival rates, estimated by the fraction of the initial numbers of plants alive per species and time interval that they were alive. Four measurements of aboveground parts were carried out by examining all plants to determine height of seedlings, which were measured from soil surface to apical parts of the primary shoot ( $0.01 \mathrm{~m}$ precision). The monitoring of individual survival was divided into three time intervals: Time Interval I, between 14 days after planting and two months, encompassing 47 days, between late February and mid April 2013; Time Interval II, from two months until the end of the first year (February 2014), encompassing
316 days, and Time Interval III, from the end of the first year to the end of the second year (February 2015), encompassing 351 days.

\section{Data analysis}

The survival of all plants per species were graphically described to show when the survival rate declined more drastically and we used Logistic Regression Analysis (Jaccard 2001) to evaluate the effects of seed size (explanatory variable) on survival (binary response variable) of the individuals in the three time intervals. This analysis is recommended when frequency data in response variables are related to continuous explanatory variables. In this analysis, the Odds Ratio predicts how the probabilities of survival vary with increases in the explanatory variable, reflecting the intensity of the effect of seed mass (Jaccard 2001; Quinn \& Keough 2002).

Relative Height Increment (RHI) was used as an estimate of growth, since the RHI and RGR (Relative Growth Rate) are strongly related (Baraloto et al. 2005). We estimated RHI for Time Interval I, II, and III as:

$$
\mathrm{RHI}=\frac{\left(\ln \frac{\text { height in time } 2)-\ln (\text { height }}{\text { (time interval in months })}\right.}{\text { (time } 1))}
$$

The relationship between RHI and mean seed mass in the three developmental periods were evaluated with linear regression (Sokal \& Rolph 1995; Quinn \& Keough 2002). The significance level used in the analyses was $\alpha$ 
$<0.05$. The residuals were graphically checked to verify trends along the estimate. Data were previously logtransformed for variance homogeneity (Sokal \& Rolph 1995). All analyses were carried out in Systat 13.0 (Systat 2009).

\section{Results}

The survival rates over time varied among species (Fig. 1). The species with the lowest survival after 24 months included C. langsdorffii (0.61) and C. legalis (0.70). On the other hand, E. timbouva and E. contortisiliquum presented survival rates equal to 1.0. Among all species, $C$. legalis was the only species whose survival rates did not stabilize over time (Fig. 1); from the beginning of the experiment until the end of the monitoring period we recorded decreases in survival. The species C. langsdorffii and C. fissilis also presented a high decrease in survival when compared to the other species but, contrary to $C$. legalis, they tended to stabilize (Fig. 1).

During Time Interval I, seed size positively influenced the probability of survival of seedlings in the field $\left(\chi^{2}=\right.$ 12.377; Odds Ratio = 3.930; p < 0.001) (Fig. 2A). Similarly, seed size positively influenced the probability of survival of seedlings at the end of Time Interval II $\left(\chi^{2}=11.546\right.$; Odds Ratio $=3.048 ; \mathrm{p}=0.001)$ (Fig. 2B) and Time Interval III $\left(\chi^{2}\right.$ $=3.899$; Odds Ratio $=2.431 ; \mathrm{p}=0.048)$ (Fig. $2 \mathrm{C}$ ), showing that species with larger seeds had a higher probability of survival than species with smaller seeds. However, the effect of seed size on plant survival in the first two time intervals were stronger than in Time Interval III.

The Relative Height Increment (RHI) varied among species during the experiment. In Time Interval I (Fig. 3A) and II (Fig. 3B), mean seed mass negatively influenced RHI. However, this relationship was weaker at Time Interval II when compared to Time Interval I. In Time Interval III, this relationship was not significant (Fig. 3C).

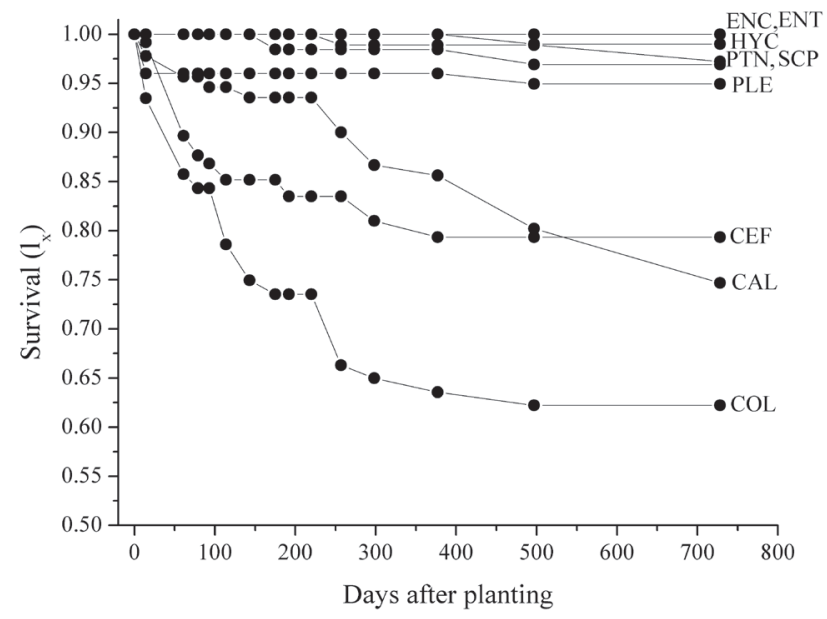

Figure 1. Survival rates of nine tree species during the experimental period. Species codes as in Table 1.

\section{Discussion}

The positive relationship between seed size and plant survival was maintained until the end of the second year after planting the seedlings. It was expected that the
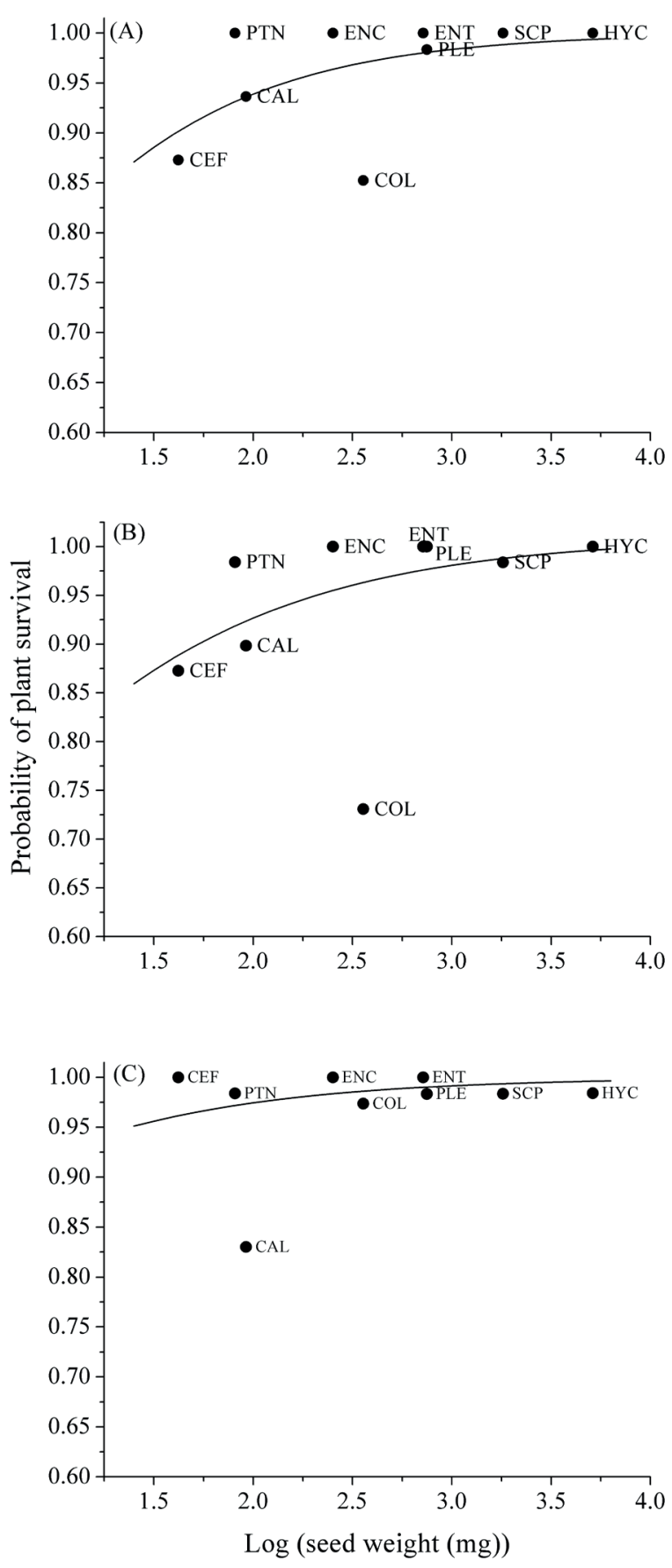

Figure 2. Relationship between the probability of survival of plants and mean seed mass of nine tree species used in the field experiment: (A) at the end of Time Interval I; (B) at the end of Time Interval II and (C) at the end of Time Interval III. Species codes as in Table 1. 

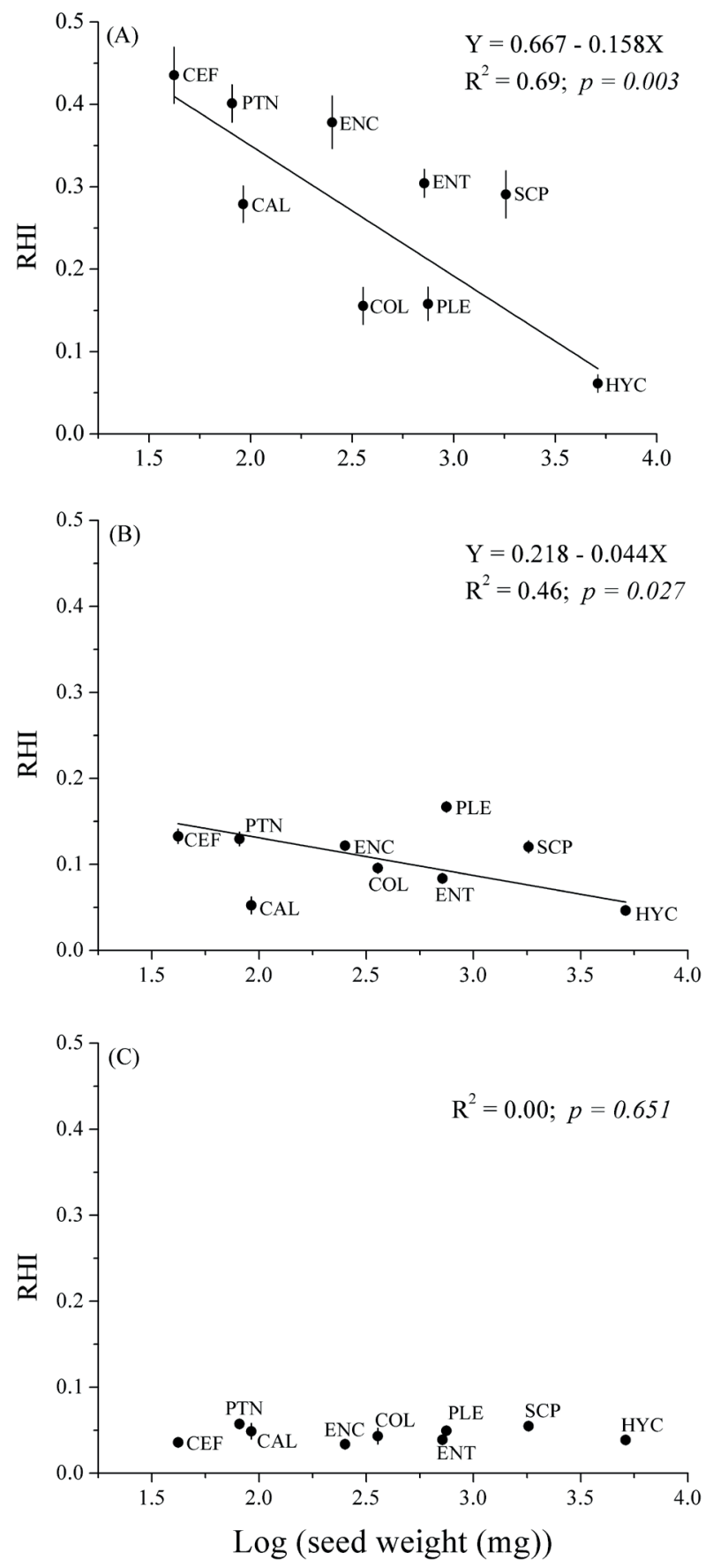

Figure 3. Relationship between Relative Height Increment (RHI) and mean seed mass of nine tree species used in the field experiment: (A) at the end of Time Interval I; (B) at the end of Time Interval II and $(C)$ at the end of Time Interval III. Bars represent standard error. Species codes as in Table 1.

mortality rates would be similar among large seed species and smaller seed species after all the seed reserves had been exhausted, since this relationship is frequently described in the literature, but only for the first developmental periods of plants introduced by direct seeding (Leishman 2001; Moles \& Westoby 2004; Green \& Juniper 2004; MartínezGarza et al. 2013; St-Denis et al. 2013; Larson et al. 2015). The persistence of the positive effect of seed mass on the probability of plant survival over time, for at least two years after planting, suggests that even after the early developmental stage of seedlings is overcome, seed size still positively influences the probability of survival of plants. This relationship can be attributed to the larger amount of energetic reserves within the cotyledons of larger seeds, the reserve effect, which would be directed for the expansion and strengthening of the root system and aboveground parts of the seedlings, guaranteeing higher absorption of nutrients and water (Green \& Juniper 2004; Soriano et al. 2013; Larson et al. 2015). Larger plants with more developed root systems have higher probability of survival (Leishman 2001; Moles \& Westoby 2004; Green \& Juniper 2004; St-Denis et al. 2013).

The negative relationship between Relative Height Increment and seed mass recorded in our experiment corroborate several other studies using different species and environments (Baraloto et al. 2005; Larson et al. 2015; Visser et al. 2016) including in the Brazilian Cerrado (Pereira et al. 2013). Turnbull et al. (2012) suggest that this relationship can be related with the strategy of growth rates among species (the fast-slow continuum hypothesis). In one extreme, species that grow fast, generally pioneering species, present high capacity to colonize new environments, whereas in the other extreme species that grow slowly have lower capacities of colonization, but with competitive advantages in the long term. Thus, pioneering species generally present smaller seeds, but higher relative growth rates when compared to non-pioneering species (late secondary or climax species), which generally present larger seeds but lower relative growth rates. However, high growth rates can be negatively related to plant survival (Wright et al. 2010). Philipson (2014), in a long-term study of 15 species in Malaysian Borneo, found that plant growth rates were positively related to mortality independently of light conditions, suggesting that there is a trade-off between traits that maximize plant growth and traits that minimize mortality. Here the relative height increment rates were negatively influenced by increases in seed mass during the first year, so that plants from larger seeds grew relatively less than those from smaller seeds.

Pioneering species are normally indicated in ecological restoration projects because they are light-dependent, have high growth rates, promote fast covering of the soil and influence the microclimate, favouring the establishment of species from later successional stages, which have larger seeds (Carpanezzi \& Carpanezzi 2006; Gris et al. 2012; Klippel et al. 2015). However, our results suggested that the higher initial relative growth rate of smaller seed species was observed only until the end of the first year after planting, while the larger seeds we recorded a higher probability of survival, which 
can extend for at least two years in the field increasing the probability of establishment of plant individuals.

Species classification into ecological groups may vary greatly between authors (Tab. 1), since it is based on many ecological characteristics (Barbosa 2009), imposing difficulties on the choice of species to be used in ecological restoration projects. Further, this categorization into ecological groups has been regarded as limited in relation to measurements of continuous variables as functional traits, because it is often done arbitrarily (Petchey et al. 2007; Pillar et al. 2013; Pierce et al. 2017). Thus, the use of functional traits could be more effective in the selection of the most appropriate species to survive in degraded areas in forest ecological restoration.

This study supported the hypothesis that seed size may be a reliable metric to predict the survival and growth rate of young plants in degraded areas. The persistence of the positive effects of seed mass on survival after the stage of seedlings suggests that other correlated functional attributes can be involved in the mechanisms of this relationship (Baraloto et al. 2005; Muller-Landau 2010; Laughlin 2014; Visser et al. 2016). It is possible that functional traits studies beyond seed mass could explain with more accuracy questions regarding the recruitment and establishment of species on degraded areas, then improving ecological restoration projects (Sandel et al. 2011). Muller-Landau (2010) proposed a model (tolerance-fecundity trade-off) to explain the coexistence of species of different seed sizes within a single habitat, since larger seed species were more likely to survive in habitats under unfavorable conditions (shade, dry and herbivory) whereas smaller seed species had the advantage of being produced in greater numbers, increasing the chances that some individuals survive. Thus, large spatial variation in stress levels could promote the coexistence of species with different seed sizes. Degraded areas have high levels of stress due to the low availability of soil nutrients, high radiation rates, low humidity and high herbivory rates, so that larger seed species would have more chances to establish in these areas. Therefore, the introduction of a greater number of individuals of small seed species in relation to the number of individuals of large seed species could be necessary to compensate for the lower survival of small seed species and to promote a higher diversity of species in these areas.

\section{Acknowledgements}

We thank Estância Dois Irmãos for the logistic support, Departamento de Botânica of Universidade Federal de São Carlos for providing equipment support for the experiments, and Conselho Nacional de Desenvolvimento Científico e Tecnológico (CNPq) for the scholarship to the first author (102986/2015-0).

\section{References}

Albuquerque LB, Alonso AM, Aquino FG, et al. 2010. Restauração ecológica de matas ripárias: uma questão de sustentabilidade. Brasília, Documentos-Embrapa Cerrados.

Baraloto C, Forget PM, Goldberg DE. 2005. Seed mass, seedling size and neotropical tree seedling establishment. Journal of Ecology 93: 1156-1166.

Barbosa LM. 2009 Considerações gerais e modelos de recuperação de formações ciliares. In: Rodrigues RR, Leitão Filho HF. (eds.) Matas Ciliares: conservação e recuperação. 2nd. edn. São Paulo, Edusp. p. 289-312.

Calderano Filho B, Santos HD, Fonseca OD, Santos RD, Primavesi O, Primavesi AC. 1998. Os solos da fazenda Canchim. Rio de Janeiro, Embrapa-CNPS.

Camargo JLC, Ferraz IDK, Imakawa AM. 2002. Rehabilitation of degraded areas of Central Amazonia using direct sowing of forest tree seeds. Restoration Ecology 10: 636-644.

Carpanezzi AA, Carpanezzi OTB. 2006. Espécies nativas recomendadas para recuperação ambiental no Estado do Paraná, em solos não degradados. Colombo, Embrapa Florestas.

Carvalho PER. 2003. Espécies Arbóreas Brasileiras. Vol. I. Brasília, Embrapa Informação Tecnológica.

Clark JS, Beckage B, Camill P, et al. 1999. Interpreting recruitment limitation in forests. American Journal of Botany 86: 1-16.

Cole RJ, Holl KD, Keene CL, Zahawi RA. 2011. Direct seeding of latesuccessional trees to restore tropical montane forest. Forest Ecology and Management 261: 1590-1597.

Cornelissen JHC, Lavorel S, Garnier E, et al. 2003. A handbook of protocols for standardised and easy measurement of plant functional traits worldwide. Australian Journal of Botany 51: 335-380.

Dalling JW, Hubbell SP. 2002. Seed size, growth rate and gap microsite conditions as determinants of recruitment success for pioneer species. Journal of Ecology 90: 557-568.

Davy AJ. 2002. Establishment and manipulation of plant populations and communities in terrestrial systems. In: Perrow MR, Davy AJ. (eds.) Handbook of ecological restoration: principles of restoration. New York, Cambridge University Press. p. 223-241.

Green PT, Juniper PA. 2004. Seed-seedling allometry in tropical rain forest trees: seed mass-related patterns of resource allocation and the 'reserve effect'. Journal of Ecology 92: 397-408.

Gris D, Temponi LG, Marcon TR. 2012. Native species indicated for degraded area recovery inWestern Paraná, Brazil. Revista Árvore 36: 113-125.

Grossnickle SC. 2012. Why seedlings survive: influence of plant atributes. New Forests 43: 711-738.

Gunaratne AMTA, Gunatilleke CVS, Gunatilleke IAUN, Madawala HMSP, Burslem DFRP. 2014. Overcoming ecological barriers to tropical lower montane forest succession on anthropogenic grasslands: synthesis and future prospects. Forest Ecology and Management 329: 340-350.

Holl KD. 1999. Factors limiting tropical rain forest regeneration in abandoned pasture: seed rain, seed germination, microclimate, and soil. Biotropica 31: 229-242.

Jaccard J. 2001. Interaction effects in logistic regression. Series on quantitative applications in the social sciences. London, Sage University Paper.

Klippel VH, Pezzopane JEM, Silva GF. 2015. Avaliação de métodos de restauração florestal de mata de Tabuleiros-ES. Revista Árvore 39: 69-79.

Lamb D. 2005. Restoring tropical moist broad-leaf forest. In: Mansouria S, Vallauri D, Dudley D. (eds.) Forest restoration in landscapes: beyond planting trees. New York, Springer. p. 291-297.

Larson JE, Sheley RL, Hardegree SP, Doescher PS, James JJ. 2015. Do key dimensions of seed and seedling functional trait variation capture variation in recruitment probability? Oecologia 181: 39-53.

Laughlin DC. 2014. Applying trait-based models to achieve functional targets for theory-driven ecological restoration. Ecology Letters 17: 771-784. 
Leishman MR. 2001. Does the seed size/number trade-off model determine plant community structure? An assessment of the model mechanisms and their generality. Oikos 93: 294-302.

Lorenzi H. 2002. Árvores Brasileiras. Vol. II, 4th. edn. Nova Odessa, Instituto Plantarum.

Martínez-Garza C, Bongers F, Poorter L. 2013. Are functional traits good predictors of species performance in restoration plantings in tropical abandoned pastures? Forest Ecology and Management 303: 35-45.

Moles AT, Westoby M. 2004. Seedling survival and seed size: a synthesis of the literature. Journal of Ecology 92: 372-383.

Muller-Landau HC. 2010. The tolerance-fecundity trade-off and the maintenance of diversity in seed size. Proceedings of the National Academy of Sciences 107: 4242-4247.

Pereira SR, Laura VA, Souza ALT. 2013. Establishment of Fabaceae tree species in a tropical pasture: influence of seed size and weeding methods. Restoration Ecology 21: 67-74.

Petchey OL, Evans KL, Fishburn IS, Gaston KJ. 2007. Low functional diversity and no redundancy in British avian assemblages. Journal of Animal Ecology 76: 977-985.

Philipson CD, Dent DH, O’Brien MJ, et al. 2014. A trait-based trade-off between growth and mortality: evidence from 15 tropical tree species using size-specific relative growth rates. Ecology and Evolution 4: 3675-3688.

Pierce S, Negreiros D, Cerabolini BE, et al. 2017. A global method for calculating plant CSR ecological strategies applied across biomes world-wide. Functional Ecology 31: 444-457.

Pillar VD, Blanco CC, Müller SC, Sosinski EE, Joner F, Duarte LD. 2013. Functional redundancy and stability in plant communities. Journal of Vegetation Science 24: 963-974.

Pilon NAL, Durigan G. 2013. Critérios para indicação de espécies prioritárias para a restauração da vegetação de Cerrado. Scientia Forestalis 41: 389-399.

Poorter H, Garnier E. 2007. The ecological significance of variation in relative growth rate and its components. In: Pugnaire FI, Valladares F. (eds.) Functional plant ecology. Boca Raton, CRC press. p. 67-100.

Quinn GP, Keough MJ. 2002.Experimental design and data analysis for biologists. Cambridge, Cambridge University Press.

Reis A, Bechara FC, Espíndola MD, Vieira NK, Souza LD. 2003. Restauração de áreas degradadas: a nucleação como base para incrementar os processos sucessionais. Natureza \& Conservação 1: 28-36.

Rolim GS, Camargo MBP, Lania DGC, Moraes JFL. 2007. Classificação climática de köppen e de thornthwaite e sua aplicabilidade na determinação de zonas agroclimáticas para o estado de São Paulo. Bragantia, Campinas 66: 711-720.

Salomão NA, Sousa-Silva JC, Davide AC, Gonzáles S. 2003. Germinação de sementes e produção de mudas de plantas do Cerrado. Brasília, Rede de Sementes do Cerrado.

Sandel B, Corbin JD, Krupa M. 2011. Using plant functional traits to guide restoration: a case study in California coastal grassland. Ecosphere 2: 1-16.

Schmidt LH. 2008. A review of direct sowing versus planting in tropical afforestation and land rehabilitation. Frederiksberg, Museum Tusculanum.

Sokal RR, Rohlf FJ. 1995. Biometry: the principles and practice of statistics in biological research. 3rd. edn. New York, Freeman.

Soriano D, Huante P, Gamboa-de Buen A, Orozco-Segovia A. 2013. Seed reserve translocation and early seedling growth of eight tree species in a tropical deciduous forest in Mexico. Plant Ecology 214: 1361-1375.

Sousa Júnior JG, Demattê JAM, Araújo SR. 2011. Modelos espectrais terrestres e orbitais na determinação de teores de atributos dos solos: potencial e custos. Bragantia, Campinas 70: 610-621.

St-Denis A, Messier C, Kneeshaw D. 2013. Seed size, the only factor positively affecting direct seeding success in an abandoned field in Quebec, Canada. Forests 4: 500-516.

Systat. 2009. Systat 13.0. San Jose, Systat Software, Inc.

Turnbull LA, Philipson CD, Purves DW, et al. 2012. Plant growth rates and seed size: a re-evaluation. Ecology 93: 1283-1289.

Visser MD, Bruijning M, Wright SJ, et al. 2016. Functional traits as predictors of vital rates across the life cycle of tropical trees. Functional Ecology 30: 168-180.

Westoby M, Falster DS, Moles AT, Vesk PA, Wright IJ. 2002. Plant ecological strategies: some leading dimensions of variation between species. Annual Review of Ecology and Systematics 33: 125-159.

Wright SJ, Kitajima K, Kraft NJB, et al. 2010. Functional traits and the growth-mortality trade-off in tropical trees. Ecology 91: 3664-3674. 